\title{
PENINGKATAN KEMAMPUAN MEMAHAMI CERITA DALAM BUKU PELAJARAN BAHASA INDONESIA MELALUI METODE ROLLING BOOK PADA SISWA KELAS V SEKOLAH DASAR NEGERI 64 TO'BULUNG KOTA PALOPO
}

\author{
Nur'Andini. SR \\ Institut Agama Islam Negeri Palopo \\ Jl. Agatis Balandai Kota Palopo \\ E-mail: andnur46@gmail.com
}

\begin{abstract}
This study is a Classroom Action Research (CAR) which is the main problem of the low ability to understand the story of the fifth grade students of SDN 64 To'Bulung Palopo in Indonesian. The subject of this research was the fifth grade students of SDN 64 To'Bulung Palopo City in the even semester of 2017/2018 school year with 25 students. This research was carried out in two cycles with folklore material. The data collection tool used consists of learning instruments, Evaluation, Documentation, and Observation. The results showed that learning outcomes with folklore material obtained student learning outcomes in cycle I was 64.08, meaning that the category had not reached the KKM score (Minimum Completeness Criteria) with the number of students completing learning were 12 students with a percentage of $48 \%$, and learning outcomes in the cycle II obtained 76.48 mean good category with the number of students complete 22 with a percentage of $88 \%$. This study was declared successful so that the use of the Rolling Book method can be used by teachers in elementary schools.
\end{abstract}

Keywords: Folklore, Rolling Book, Indonesian Language Learning.

\begin{abstract}
Abstrak
Penelitian ini adalah Penelitian Tindakan Kelas (PTK) yang masalah utama rendahnya kemampuan memahami cerita pada siswa kelas V SDN 64 To'Bulung Kota Palopo mata pelajaran Bahasa Indonesia. Subjek penelitian ini adalah siswa kelas V SDN 64 To'Bulung Kota Palopo pada semester genap tahun pelajaran 2017/2018 dengan jumlah siswa 25 orang. Penelitian ini dilaksanakan dua siklus dengan materi cerita rakyat. Alat pengumpul data yang digunakan terdiri dari instrument pembelajaran, Evaluasi, Dokumentasi, dan Observasi. Hasil penelitian menunjukkan bahwa hasil belajar dengan materi cerita rakyat diperoleh hasil belajar siswa pada siklus I adalah 64,08 termaksud kategori belum mencapai nilai KKM (Kriteria Ketuntasan Minimal) dengan jumlah siswa tuntas belajar adalah 12 siswa dengan peresentase 48\%, dan hasil belajar pada siklus II rata rata diperoleh 76,48 termaksud kategori baik dengan jumlah siswa tuntas 22 dengan persentase $88 \%$. Penelitian ini dinya takan berhasil sehingga penggunaan metode Rolling Book dapat digunakan oleh guru di Sekolah Dasar.
\end{abstract}

Kata Kunci,: Cerita Rakyat, Rolling Book, Pelajaran Bahasa Indonesia.

\section{PENDAHULUAN}

Kebiasaan membaca anak-anak ditingkat pendidikan dasar masih rendah. Berdasarkan survei yang pernah dilakukan mencatat, kemampuan membaca anak Sekolah Dasar di Indonesia menempati peringkat ke-26 dari 27 negara yang 
disurvei. Fakta itu diperteguh hasil penelitian Programme for International Student Assesment (PISA) Tahun 2003 yang diseleranggakan oleh 80 negara anggota Organization for Economic Cooperation and Development (OECD). Penelitian tersebut menyimpulkan, kemampuan membaca anak-anak Indonesia usia 9-14 tahun berada pada urutan terbawah. Adapun yang diukur oleh Programme for International Student Assesment (PISA) adalah kemampuan menafsirkan teks, serta kemampuan mengolah dan memberikan makna pada teks tersebut'. R Masri Sareb Putra (2008:131). Peringkat dan pencapaian nilai programme for International Student Assessment (PISA) Indonesia untuk 2015 meningkat enam peringkat dari peringkat 71 pada 2012. Sementara, berdasarkan nilai median kompetensi membaca siswa Indonesia meningkat dari 337 poin di tahun 2012 menjadi 350 poin pada 2015',. Indriani (2016: 2). Hasil Programme for International Student Assesment (PISA) tahun 2015 Yang menunjukkan Indonesia baru bisa menduduki peringkat 69 dari 76 negara". Billy Khaerudin (2016:1). Sehingga perlu adanya inisiatif dari semua pihak untuk meningkatkan kemampuan membaca siswa.

Semakin banyak dan sering seseorang membaca semakin kaya pula ia akan pengetahuan dan pengalaman, yang berarti semakin banyak pula modal yang dimilikinya untuk membaca'. Nurhadi (2016:14). Bacalah dengan menyebut nama Tuhanmu yang Menciptakan, Dia Telah menciptakan manusia dari segumpal darah. Bacalah, dan Tuhanmulah yang Maha Pemurah, Yang mengajar (manusia) dengan perantara kalam, Dia mengajar kepada manusia apa yang tidak diketahuinya". Departemen Agama Republik Indonesia (2010:597). Semakin banyak membaca semakin banyak peluang untuk memahami sesuatu.

"Memahami ialah yang berasal dari kata paham atau pemahaman dapat diartikan menguasai sesuatu dengan pikiran." Sardiman (2011:42-43). Menurut kamus besar bahasa Indonesia, kemampuan diartikan sebagai kesanggupan, kecakapan, kekuatan'. (2011:707) Menurut Bloom dalam buku Ahmad Susanto "pemahaman dapat diartikan sebagai kemampuan untuk menyerap arti dari materi atau bahan yang dipelajari”. (2013:6) Sedangkan menurut Anderson yang telah merevisi Taksonomi Bloom ialah Taksonomi Bloom menjadi Taksonomi Bloom dua dimensi, yang terdiri dari dimensi proses kognitif (proces kognitif dimension) dan dimensi pengetahuan (Knowledge dimension)." Rizki Ananda dan Fadhilaturrahmi( 2016:14). Melalui taksonomi Bloom inilah telah berhasil memberikan inspirasi kepada banyak pakar pendidikan dalam mengembangkan teori-teori maupun praktek pembelajaran', Asri Budinigsih (2012:75). Sehingga perlu adanya pengembangan teori dalam pembelajaran.

Menurut McLaughin dan Allen dalam buku Farida Rahim mengemukakan prinsip-prinsip membaca yang didasari pada penelitian yang mempengaruhi pemahaman membaca ialah pemahaman merupakan proses kontruktivis social, keseimbangan kemahiraksaraan yang dinamis menginformasikan pembelajaran PiJIES: Pedagogik Journal of Islamic Elementary School 
membaca pemahaman"' (2008:4). Menurut Lado Membaca pemahaman adalah pemahaman arti atau maksud dalam suatu bacaan melalui tulisan. Definisi ini sangat menekankan pada dua hal yang pokok dalam membaca, yaitu bahasa itu sendiri dan simbol grafik tulisan yang menyajikan informasi yang berwujud bacaan". Lado (2015:9). Sehingga memahami suatu bacaan itu membutuhkan pemahaman untuk mencapai tujuan dari memahami bacaan.

Buku merupakan salah satu media pembelajaran terbaik bagi anak-anak. Oleh karena itu, buku adalah salah satu media yang tepat'. Jasa Ungguh Muliawan (2013:149). Buku adalah sumber energi dan motivasi. Seorang guru harus menjadi pembaca intensif dari buku-buku perpustakaan'. Nuni Yusvavera Syatra (2013:149). Sehingga buku menjadi sumber utama yang dibutuhkan siswa.

Pembelajaran Bahasa Indonesia di Sekolah Dasar diarahkan untuk meningkatkan kemampuan siswa dalam komunikasi dan pembelajaran Bahasa Indonesia juga diharapkan dapat menumbuhkan apresiasi siswa terhadap hasil karya sastra Indonesia', Zulela (2013:4). Belajar dapat diartikan sebagai proses kognitif yang kompleks dalam mengubah sifat merangsang dari lingkungan menjadi beberapa tahap pemrosesan informasi untuk mendapatkan kemampuan baru (Rustan, 2017). Sehingga belajar dan bahasa itu menjadi penting dalam menyampaikan pendapat untuk dipahami serta mengetahuai kemampuan seseorang.

Metode Rolling Book ialah buku bergulir aktivitasnya, siswa menuliskan jawaban soal di dalam buku atau kertas (bisa pendapat, sebuah solusi alternatif, jawaban soal, dan sebagainya) kemudian mengedarkannya dan saling memberikan tindak lanjut". Lubis Grafura (2008:73-74). Menurut Slavin hasil penelitian 20 tahun terakhir mengindikasikan bahwa pendekatan belajar kooperatif bisa digunakan secara efektif pada setiap tingkat kelas untuk semua mata pelajaran". Farida Rahim ( 2008:34). Sehingga penting penggunaan pendekatan belajar kooperatif untuk meningkatkan mutu pembelajaran.

Cerita rakyat merupakan bentuk karya sastra lama. Dimana terdapat unsur instrisik yang terkandung didalamnya yaitu tokoh, tema, amanat, watak, latar'. Sri Rahayu dan Yanti Sri R (2009:37-38). Metode Cooperative Integrated Reading And Composition (CIRC) dengan melihat langkah-langkahnya membentuk kelompok yang anggotanya 4 orang yang secara heterogen. Guru memberikan wacana/kliping sesuai dengan topik pembelajaan Siswa bekerja sama saling membacakan dan menemukan ide pokok dan memberikan tanggapan terhadap wacana/kliping dan ditulis pada lembar kertas'. Agus Suprijono (2008:130-131). Model Pair Checks (pasangan mengecek) merupakan model pembelajaran di mana siswa saling berpasangan dan menyelesaikan persoalan yang diberikan. Model ini bertujuan untuk meningkatkan kemampuan siswa dalam menuangkan ide, pikiran, pengalaman, dan pendapatnya dengan benar'. Dengan belajar berkelompok siswa akan saling memahami persamaan yang mereka miliki sehingga siswa lebih percaya diri akan kemampuan yang 
dimilikinya (Rustan, 2010). Timbulnya kepercayaan diri siswa akan menimbulkan rasa aman sehingga lebih mudah dalam berkomunikasi. Kepercayaan diri yang timbul berpengaruh terhadap motivasi belajar sehingga keberhasilan akademik juga dapat meningkat (Rustan \& Bahru, 2018). Aris Shoimin (2014:119). Perlu adanya metode serta inovasi terbaru untuk meningkatkan mutu pembelajaran.

Berdasarkan pra tindakan yang dilakukan oleh peneliti pada Sekolah Dasar Negeri 64 To'Bulung Kota Palopo yaitu permasalahan pada observasi awal yang peneliti temukan berdasarkan pengamatan saat pembelajaran berlangsung, siswa kurang antusias dan malas ketika diberi tugas untuk membaca, ternyata siswa merasa bosan dengan cara guru yang mengajar monoton. Setiap kali pembelajaran membaca guru hanya menyuruh siswa membaca dalam hati sebuah teks atau bahan bacaan secara individu, atau menyuruh salah satu siswa itu untuk membaca secara nyaring. Akibatnya, siswa tidak mengetahui bagaimana cara memahami cerita rakyat dalam buku pelajaran Bahasa Indonesia. Untuk mengetahui sejauh mana pemahaman siswa terhadap materi yang diberikan yaitu dengan melakukan observasi dan memberikan tes awal. Dari 25 siswa yang menjadi sampel sekaligus ikut dalam melakukan tes awal ternyata terdapat 20 siswa atau sebesar $80 \%$ yang mendapatkan nilai termaksud kategori sangat kurang, 1 siswa atau sebesar 4\% siswa yang mendapat nilai termasuk kategori kurang, kemudian terdapat 2 siswa atau sebesar $8 \%$ yang mendapat nilai termasuk kategori cukup, dan ada 2 siswa atau sebesar $8 \%$ yang mendapatkan nilai termasuk kategori baik dan belum ada siswa yang mendapat kategori sangat baik.

Alasan tersebut mendorong peneliti untuk melaksanakan penelitian dengan menggunakan metode Rolling Book untuk meningkatkan kemampuan memahami cerita siswa. Dalam menerapkan metode Rolling Book ada beberapa langkahlangkah penerapannya antara lain: Permainan ini bisa dilakukan dengan guru memberikan soalpermasalahan ,masing-masing kelompok menuliskan jawabannya di buku tulis guru menginstruksikan setiap kelompok siswa memberikan buku miliknya kepada kelompok di sebelah kanannya, setiap kelompok akan mendapatkan buku dari temannya. kegiatan ini dilakukan beberapa kali sampai dianggap cukup." Lubis Grafura (2008:73-74). Metode ini untuk mempermudah siswa dalam menyampaikan pendapatnya dari pemahaman yang dimiliki.

\section{METODE}

Objek tindakan yang dilakukan dalam penelitian tindakan kelas (Classroom Action Research) ini adalah untuk peningkatan kemampuan memahami cerita dalam buku pelajaran Bahasa Indonesia melalui metode Rolling Book pada siswa kelas V Sekolah Dasar Negeri 64 To'Bulung Kota Palopo. Pada prinsipnya

PiJIES: Pedagogik Journal of Islamic Elementary School 
pelaksanaan tindakan yang dilakukan dalam penelitian ini mengikuti Model Kurt Lewin yang menjelaskan bahwa ada 4 hal yang harus dilakukan dalam proses penelitian yakni Perencanaan, Tindakan, Observasi, Refleksi', Wina Sanjaya (2009:49-50).

Penelitian ini dilaksanakan di Sekolah Dasar Negeri 64 To'Bulung Kota Palopo. 1) Sumber Data, pada penelitian ini peneliti menggunakan dua jenis data untuk mendukung penelitiannya adalah: a) Data primer adalah data dikumpulkan atau diolah sendiri oleh peneliti dengan mendatangi sumbernya'. Subana dkk (2000: 21). Observasi dengan pihak sekolah terkhususnya kepala Sekolah dan guru kelas V Sekolah Dasar Negeri 64 To'Bulung Kota Palopo. b) Data sekunder ialah data yang didapatkan dari data tertulis berupa profil sekolah, data guru, data siswa, serta sarana dan prasarana yang ada di sekolah tersebut yang dibutuhkan untuk kelengkapan dalam penelitian. 2) Subjek Penelitian, Subjek penelitian adalah siswa-siswi kelas V Sekolah Dasar Negeri 64 To'Bulung Kota Palopo,berjumlah 25 siswa yang terdiri dari 14 laki-laki dan 11 perempuan pada semester genap tahun pelajaran 2017/2018.

Pengelolaan data dilakukan setelah terkumpulnya data pada penelitian. Selanjutnya dianalisis secara kuantitatif dan kualitatif. Untuk analisis secara kuantutatif digunakan analisis secara statistik deskriptif yaitu skor rata-rata dan persentase. Sedangkan analisis kualitatif dilakukan terhadap data yang diperoleh melalui observasi aktivitas belajar siswa dan guru dalam penerapan Metode Rolling Book untuk meningkatkan kemampuan memahami cerita. Analisis ini dihitung dengan menggunakan rumus persentase sederhana, Amirul dan Haryono (2005:154-155). $\quad P=\frac{f}{n} \mathrm{x} 100 \%$ menjumlahkan semua nilai yang diperoleh siswa selanjuatnya dibagi dengan jumlah siswa sehingga diperoleh nilai rata-rata, dari hasil penelitian yang telah didapatkan tersebut kemudian diklasifikasikan kedalam bentuk penskoran nilai siswa dengan menggunakan kategori Persentase Skor penilaian. Wayan Nurkancana dan Sunartana (2011:93) bila target kategori tuntas $70 \%-100 \%$ dan subyek $<40 \%$ berada dalam kategori tidak tuntas.

\section{HASIL PENELITIAN}

Bentuk penerapan metode Rolling Book dalam meningkatkan kemampuan memahami cerita pada siswa dengan menyediakan penerapan penggunaan metode Rolling Book dalam pembelajaran metode ini siswa saling bekerja sama dalam kelompok kooperatif untuk membaca bahan bacaan, menganalisis unsur-unsur instrinsik, menjawab pertanyaan, hingga mempresentasikan hasil diskusinya di depan kelas. Penerapan metode ini dilakukan selama tiga kali pertemuan setiap siklusnya Sehingga dengan diterapkannya metode Rolling Book dapat meningkatkan kemampuan memahami cerita rakyat pada siswa kelas $\mathrm{V}$ di Sekolah Dasar Negeri 64 To'Bulung Kota Palopo. Penggunaan metode Rolling Book dalam pembelajaran Bahasa Indonesia khususnya memahami cerita rakyat 
ini digunakan untuk mempermudah kemampuan memahami siswa dalam membaca bacaan cerita rakyat. Hal-hal yang meningkat yaitu kinerja selama pembelajaran yang mencakup pemahaman, antusias, keaktifan dan konsentrasi. Penggunaan metode Rolling Book dalam pembelajaran Bahasa Indonesia khususnya memahami cerita rakyat ini digunakan untuk mempermudah kemampuan memahami siswa dalam membaca bacaan cerita rakyat.

Setelah peneliti menerapkan metode Rolling Book pada siswa kelas V Sekolah Dasar Negeri 64 To'Bulung Kota Palopo, dapat diketahui pada kemampuan memahami siswa selalu meningkat. Berdasarkan materi yang telah diajarkan melalui metode Rolling Book untuk mengetahui sejauh mana pemahaman siswa terhadap materi yang diberikan. Melihat dari hasil evaluasi baik dari segi kognitif, afektif, dan prikomotorik, dapat dikatakan bahwa indikator kerja yang telah ditetapkan dalam perbaikan pembelajaran yang berjudul Peningkatan kemampuan Memahami Cerita dalam Buku Pelajaran Bahasa Indonesia melalui Metode Rolling Book pada Siswa Kelas V Sekolah Dasar Negeri 64 To'Bulung Kota Palopo Semester II Tahun Pelajaran 2017/2018 dapat tercapai. Berikut diagram ketuntasan nilai evaluasi siswa.

Diagram ketuntasan nilai e valuasi siswa pada siklus I dan II Sekolah Das ar Negeri 64 To'Bulung Kota Palopo

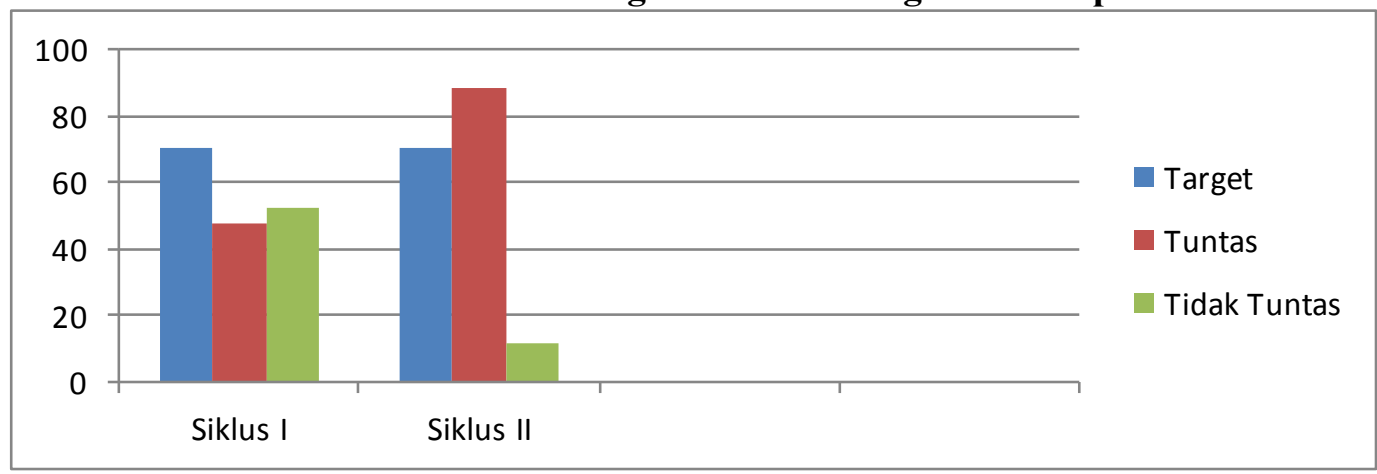

Diagram tersebut menunjukkan bahwa peningkatan kemampuan memahami cerita dalam buku pelajaran Bahasa Indonesia pada siswa mengalami peningkatan dalam setiap siklusnya. Melihat dari data ketuntasan siswa diatas, terjadi peningkatan dimana pada siklus I ketuntasan siswa hanya 12 dari 25 siswa dengan presentase $48 \%$ dan naik pada siklus II dengan ketuntasan 22 dari 25 siswa dengan presentase 88\%. Sehingga mencapai nilai KKM (Kriteria Ketuntasan Minimal).

\section{PEMBAHASAN RUMUSAN MASALAH KEDUA}

Pembahasan hasil penelitian yakni bentuk penerapan metode Rolling Book dalam meningkatkan kemampuan memahami cerita pada siswa dengan menyediakan penerapan penggunaan metode Rolling Book dalam pembelajaran PiJIES: Pedagogik Journal of Islamic Elementary School 
metode ini siswa saling bekerja sama dalam kelompok kooperatif untuk membaca bahan bacaan, menganalisis unsur-unsur instrinsik, menjawab pertanyaan, hingga mempresentasikan hasil diskusinya di depan kelas.

Adapun teori Anderson yang merevisi Taksonomi Bloom yang menyatakan bahwa memahami yaitu membangun pengetahuan dari pesan pembelajaran, termasuk komunikasi lisan, tertulis, dan grafis". Rizki Ananda dan Fadhilaturrahmi ( 2016:14). Sehingga dapat terjadi perbedaan nilai hasil memahami cerita dalam setiap siklusnya salah satunya disebabkan adanya perhatian yang besar dalam belajar, menunjukkan antusiasme atau minat dalam belajar dan mengajukan pertanyaan kepada guru tentang materi yang dipelajari, dan mampu memberikan pendapat dari bacaan yang dipahaminya khususnya dalam pembelajaran Bahasa Indonesia sehingga proses pembelajaran menjadi semakin lebih baik sesuai dengan yang diharapkan dan siswa sepenuhnya telah terlihat aktif dalam proses pembelajaran. Menurut Lado Membaca pemahaman adalah pemahaman arti atau maksud dalam suatu bacaan melalui tulisan. Definisi ini sangat menekankan pada dua hal yang pokok dalam membaca, yaitu bahasa itu sendiri dan simbol grafik tulisan yang menyajikan informasi yang berwujud bacaan". Firman (2015:9) Sehingga siswa mampu menuliskan pendapatnya sendiri dari bacaan yang dipahaminya dalam pembelajaran Bahasa Indonesia. Menurut Slavin hasil penelitian 20 tahun terakhir mengindikasikan bahwa pendekatan belajar kooperatif bisa digunakan secara efektif pada setiap tingkat kelas untuk semua mata pelajaran'. Farida Rahim (2008:34). Sehingga penelitian ini menggunakan pendekatan belajar kooperatif dengan penggunaan metode Rolling Book yang menjadi bagian dari pembelajaran Kooperatif yang dapat membuat pembelajaran menjadi efektif serta hal-hal yang meningkat dalam penelitian ini yaitu kinerja selama pembelajaran yang mencakup pemahaman, antusias, keaktifan dan konsentrasi.

\section{PENUTUP}

Hasil analisis data penelitian, serta rumusan masalah maka dapat disimpulan bahwa: 1) kegiatan pembelajaran bahasa Indonesia khususnya membaca memahami cerita rakyat dengan menggunakan metode Rolling Book memberikan pengaruh yang positif. Ini dibuktikan dengan dapat meningkatkan proses pembelajaran Memahami cerita rakyat pada siswa kelas V SDN 64 To'Bulung. Hal-hal yang meningkat yaitu kinerja selama pembelajaran yang mencakup pemahaman, antusias, keaktifan dan konsentrasi. Penggunaan metode Rolling Book dalam pembelajaran bahasa Indonesia khususnya memahami cerita rakyat ini digunakan untuk mempermudah kemampuan memahami siswa dalam membaca bacaan cerita rakyat. Dalam metode ini siswa saling bekerja sama dalam kelompok kooperatif untuk membaca bahan bacaan, menganalisis unsur-unsur instrinsik, menjawab pertanyaan, hingga mempresentasikan hasil diskusinya di 
depan kelas. 2) Melalui penggunaan metode Rolling Book dapat meningkatkan kemampuan memahami cerita rakyat pada siswa kelas V Sekolah Dasar Negeri 64 To'Bulung. Hasil tes pra siklus atau kondisi awal sebelum dilaksanakan dengan nilai rata rata adalah 49,96 dengan persentase ketuntasan klasikal sebesar $16 \%$, siklus I menghasilkan nilai rata-rata kelas 64,08 dengan persentase ketuntasan klasikal 48\%, dan siklus II menghasilkan nilai rata-rata kelas 76,48 dengan persentase kelulusan klasikal 88\%. Dengan demikian secara klasikal, pembelajaran telah mencapai ketuntasan belajar sesuai dengan target yang ditetapkan.

\section{DAFTAR PUSTAKA}

Abdullah, Hakim, Peningkatan Kemampuan Membaca Pemahaman melalui Penggunaan Metode Cooperative Integrated Reading and Composition (CIRC) Bagi Siswa kelas V SDN Temanggal, Kalasan Kabupaten Sleman Jawa Tengah Tahun Pelajaran 2013/2014, (Perpustakaan Universitas Negeri Yogyakarta 2014.

Adnan Fazlia Purnama dan Yamin M, Kemampuan Mengungkapkan Kembali Cerita Melalui Bahasa Tulis Siswa Kelas IV Sekolah Dasar Negeri Mutiara Kecamatan Sawang Kabupaten Aceh Selatan, Unsyiah Aceh. Vol. 2 Nomor 4, 2017.

Ananda Rizki dan Fadhilaturrahmi, Evaluasi Pembelajaran IPS Berbasis Taksonomi Bloom Dua Dimensi Di Sekolah Dasar, vol.1 no.2 Juli 2016, h. 14. http:// stkiptam.ac.id/indeks.php/basicedu 02, April 2018.

Budinigsih, Asri, 2012, Belajar \& Pembelajaran, Cet II; Jakarta:Rineka Cipta.

Departemen Agama RI, Al - Qur'an Terjemahan, Cet I; Bandung: CV Diponegoro, 2007.

Firman, 2015, Terampil Menulis Karya Ilmiah, Cet I; Makassar: Aksara Timur.

Grafura Lubis et.al., 2008, 40 Seni Manajemen Kelas, Cet I; Jakarta: Ar-Ruz.

Hadi Amirul ,dan Haryono, 2005, Metodologi Penelitian Pendidikan, Cet. III; Bandung: Pustaka Setia.

Indriani, Peringkat PISA Indonesia Alami Peningkatan, Antaran News. https://www.antaranews.com/berita/600165/peringkat-pisa-

indonesia-alami- peningkatan 06 Desember 2016.

Khaerudin, Billy Rangking Pendidikan Dunia Tahun 2015 Indonesia, Chirpstory. https://chirpstory.com/li/339551 09 Desember 2016.

Muliawan Jasa Ungguh, 2016, 45 Model Pembelajaran Spektakuler, Cet I; yogyakarta : Ar- Ruzz Media.

PiJIES: Pedagogik Journal of Islamic Elementary School 
Nurhadi, 2016, Strategi Meningkatkan Daya Baca, Cet I; Jakarta: Bimi Aksara. Nurjan, S., dan Rustan E, 2010, Kunci Sukses Belajar Bahasa Indonesia, Cet I; Lembaga Penerbitan STAIN LPS STAIN Palopo.

Nurkancana, Wayan dan Sunartana, 2011, Evaluasi Hasil Belajar, Cet I; Yogyakarta:Usaha Nasional.

Putra, R Masri Sareb, 2008, Menumbuhkan Minat Baca Sejak Dini, Cet I; Jakarta : Indeks,

Rahayu Sri dan R Yanti Sri, 2009, Bahasa Indonesia untuk SD/MI Kelas V, Cet. I; Jakarta; Pusat Perbukuan Departemen Pendidikan Nasional.

Rahim, Farida, 2008, Pengajaran Membaca disekolah dasar, Cet. II :Jakarta : Sinar Grafika.

Rustan, E. (2010). Pembelajaran Bahasa dan Sastra Daerah Berbasis Multikultural dalam Mewujudkan Pendidikan yang Berkarakter di Era Globalisasi. In Hanna, Firman, \& S. Safitri (Eds.), Kongres Internasional Bahasa-bahasa Daerah Sulawesi Tenggara (pp. 247-249). Baubau.

Rustan, E. (2017). Learning Creative Writing Model Based on Neurolinguistic Programming. International Journal of Language Education and Culture Review, 3(2), 13-29. https://doi.org/10.21009/IJLECR.032.02

Rustan, E., \& Bahru, M. S. (2018). Penguatan Self Confidence dalam Pembelajaran Matematika melalui Metode Suggestopedia. Al-Khwarizmi: Jurnal Pendidikan Matematika Dan Ilmu Pengetahuan Alam, 6(1), 1-14.

Sanjaya, Wina, 2009, Penelitian Tindakan Kelas, Cet. I; Jakarta: Prenamedia Group.

Sardiman, 2011, Interaksi dan Motivasi Belajar Mengajar, Cet II; Jakarta: Rajawali Pers.

Subana et.al., 2000, Statistik Pendidikan (untuk Fakultas Tarbiyah, Bandung : Pustaka Setia.

Shoimin, Aris, 2014, 68 Model Pembelajaran Inofatif dalam Kurikulum 2013, Cet I; Yogyakarta: Ar-Ruzz Media.

Suprijono, Agus, 2008, Cooperatif Learning Teori \& Aplikasi PAIKEM, Cet I; Jakarta: Sinar Grafika.

Susanto, ahmad, 2013, Teori dan Pembelajaran di Sekolah Dasar, Cet I; Jakarta: Kencana.

Syatra Nuni Yusvavera, 2013, Desain Efektif Guru dan Murid, Cet I; yogyakarta: Buku Biru, 
112 | Nur' Andini. SR

Tim Penyusun Kamus Pusat Bahasa- ed.3, Kamus Besar Bahasa Indonesia, Cet. IV. Jakarta; Balai Pustaka, 2007.

Zulela, 2013, Pembelajaran Bahasa Indonesia Apresiasi sastra di Sekolah Dasar, Cet II; Bandung: Remaja Rosdakarya.

PiJIES: Pedagogik Journal of Islamic Elementary School 